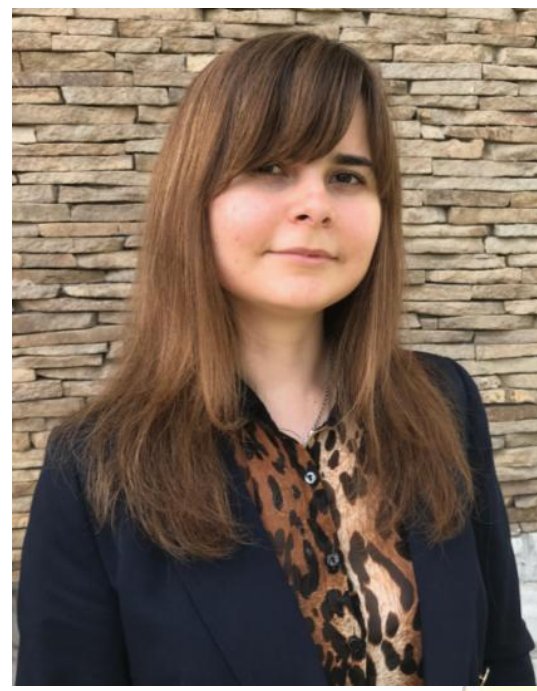

\title{
COMPARATIVE ANALYSIS OF DEMILITARIZED AND NEUTRALIZED TERRITORIES IN INTERNATIONAL LAW
}

\author{
Roianova Inna Volodimirovna, \\ Post-graduate Student of the Department \\ of International Law, \\ Yaroslav Mudryi National Law University, \\ Ukraine, Kharkiv \\ e-mail:iv.roianova@gmail.com \\ ORCID 0000-0002-0443-1815
}

Different approaches to the definitions of "demilitarized zone" and "neutralized territory" were analyzed. The overview of international practice has provided an opportunity to make the following conclusions as to the identity of these phenomena before the First World War and their regulation by peace agreements after. Aftermath of the world wars there were mostly cases of conclusion of bilateral and multilateral agreements that envisaged either demilitarization or neutralization of territories, or both options at the same time. Clarification is made on the following approach of defining demilitarization as a synonym for disarmament. In particular, it is concluded that the latter is an integral part of demilitarization and demobilization. It is proved to be inappropriate to identify the concepts of "neutralization" and "neutrality" since the latter determines the legal status of a State, whereas neutralization defines the legal status of a part of a State. Based on the comparative analysis of demilitarized and neutralized regimes, applying the criteria of their objectives, legal framework and duration of functioning, common and distinctive features of such regimes could be defined. It is summarized that demilitarization and neutralization of territories provide peace and security, and serves for a prevention of armed conflicts, having positive effect on the settlement of post-war disputes between States.

Key words: demilitarization; neutralization; demilitarized territories; disarmament; neutrality; the Aland Islands.

Problem setting. There are a variety of prohibitions on armaments and military activities to be undertaken by any State with regard to demilitarized zones and neutralized territories. Specific restrictions imposed within abovementioned territories have different application, giving us an opportunity to distinguish between the notions concerned, particularly regarding the established legal regime of such areas.

Analysis of recent research and publications. The issues of demilitarization and neutralization of territories as an alternative measure of resolving armed conflicts were the objectives of research of legal scholars, including C. Ahlström, 
S. Åkermark, H. Arthur, M. Chillaud, N. Dyn, V. Holytsyn, B. Klymenko, R. Mamedov, J. Marshall-Cornwall, V. Semenov. A significant number of academic researches focus on demilitarization and neutralization of the Åland Islands, the Svalbard archipelago and the Antarctic continent. In particular, demilitarization of space is a matter of scientific interest for most of the mentioned scholars.

Statement of the article objective. International legal regulation of demilitarized zones and neutralized territories provides three general legal regimes covering State's territory, territory with an international regime and territory of a mixed regime, in addition to a number of special regimes, for example, the regime of high seas or the regime established for the purpose of peace and security [1, p. 159]. The latter applies to demilitarized zones and neutralized territories, which are the focus of the present scientific research. Hence, it would be reasonable to define the concepts concerned.

Presentation of the main body of the article. Before the First World War the notions of 'demilitarization' and 'neutralization' were considered practically identical phenomena [2, p. 5]. Moreover, a variety of treaties concluded during this period of history provided a detailed description of prohibited military measures in a part of a territory without defining them as demilitarization or neutralization. Furthermore, there were numerous international agreements, which regulated the regimes of neutralized areas. The analysis of their provisions gives an opportunity to conclude that these agreements actually referred to demilitarization of such territories. For example, the Svalbard archipelago, which lies to the north of Norway between the Greenland and Barents seas became neutrilized under the Protocol concluded in Oslo in January 1912 by Norway, Russia and Sweden. The Spitsbergen Treaty of Febuary 9, 1920, which granted Norway the sovereignty over Svalbard reintroduced this status. However, Article 9 of the Spitsbergen Treaty stipulates that "neither to create nor to allow the establishment of any naval base in the territories specified in Article 1 and not to construct any fortification in the said territories, which may never be used for warlike purposes" [2, p. 23]. Accordingly, in this case the treaty provided both : neutrilization and additionally demilitarization of the arcipelago. 
J. Marshall-Cornwall noticed that 'term 'demilitarization' could not be found in any prewar dictionaries " [3, p. 46-47], whereas some scholars concluded that the term 'demilitarization' has been an achivement of the Paris Peace Conference (January 19, 1919 - January 21, 1920), as the appropriate definition of such regime was formulated as a result of the process of demilitarization within Rhines, where Germany as a defeated party "was prohibited having neither arms nor installations" [3, p. 46-47]. Articles 42-44 of the Treaty of Versailles of 28 June, 1919, laid down that Germany could have no fortification or military establishment of any sort on the left bank of the Rhine and in an area fifty kilometres east from the river. Subsequently, the term of 'demilitarization' established in international law had to be interpreted as a part of a territory or zone, where all kinds of weapons, arm installations and deployment of military forces were prohibited [4, p. 7].

It woud not be an exaggeration to mention that neutrilization has been applied in several treaties to the phenomenon that should be defined as demilitarization. For instance, under Article 60 (1) of the Protocol Additional to the Geneva Conventions of 12 August 1949, and relating to the Protection of Victims of International Armed Conflicts of June 8, 1977, "it is prohibited for the Parties to the conflict to extend their military operations to zones on which they have conferred by agreement the status of demilitarized zone, if such extension is contrary to the terms of this agreement" [5].

The Rapporteur of Committee III noted that "it was difficult to find an adequate term to describe the protected zones which it was felt should be created" [6]. It is worth to emphasized that, trying to define the notion of 'demilitarization', the Rapporteur distinguished between the terms 'neutralized zones' and 'nonmilitarized zones' and even the French term 'zones civilisées' but finally the term 'demilitarized zones' was applied [6]. It is necessary to mention C. Ahlström's point of view, according to which "there are examples where terms have been defined on an ad hoc basis, i.e. the definitions employed apply only to the specific conditions regulated by the treaty and are not intended to create a general definition" [7, p. 15].

According to Merriam Webster dictionary, 'to demilitirize' means to prohibit 
something, such as a zone or frontier area from being used for military purposes [8]. J. Salmone defined demilitarization as "a measure which consists of banning the presence of military forces and installations, all military exercises or any kind of armament testing, in a certain geografic area. The measure may possibly entail the destruction of existing military structures" [9]. Thus, the following opinion of M. Chillaud is mostly applicable for the purposes of the present research as "demilitarisation instruments prohibit the introduction or maintaince of fortifications, and the presence or increase of armed forces and their equipment, in an area with the explicit or implicit aim of preventing conflict" [2, p. 5-6]. In addition, B. Klimenko pointed out that "demilitarization provide an obligation between states under international treaty in the certain territory to demolish millitary installations and structures as well as millitary forces; it could be full and partial" [4, p. 11].

Some scholars specialized on international law considered demilitarization a synonym of disarmament. It can be argued that these terms have no differences in meaning. Disarmament consists of the collection, control and disposal of small arms, ammunition, explosives light and heavy weapons from combatants and the civilian population. In this context C. Gleichmann asserted that the explicit objective of disarmament was to reduce the number of weapons circulating among countries population, as well as reducing the threat of violence to human security [10, p. 29]. Presumably, disarmament refers to measures connected with reducing of weapons whereas demilitarization is supposed to define the range of activities, including disarmament, within a certain territory. Thus, the latter has a broader meaning than disarmament as it involves a complex of operations for disarmament, demobilization and reintegration (DDR). DDR is part of the peace process and an essential confidence-building measure [10, p. 17]. Thus, demilitarization covers, inter alia, disarmament as its major component.

The observation of S. Spiliopoulouthat the main aim of the demilitarization was to reduce an armament and military presence in a certain geographical area, as well as to ensure that a delimited territory would not be fortified and therefore would be less attractive for military purposes has been supported by a number of scholars 
$[11$, p. 5].

Other approaches to define demilitarization could be found in legal researches. Kingma and Schrijver defined this term having determining its antonym 'militarization'. These authors described latter as "the complex process of mobilization of resources for armed conflict at political, economic and social levels, with high level influence of the military in the society" [12]. According to the mentioned conclusion, demilitarization is also complex of operations which includes the opposite measures, for instance, demobilization or disarmament.

Most scholars would agree that demilitarization and neutralization of territories are both the special regimes established by international agreements aimed at preventing armed conflicts. However, demilitarization could also mean that no fortifications or permanent military structures might exist within demilitarized territory. For example, Part D of the Anex XIII to the Treaty of Peace with Italy of February 10, 1947, signed between the Allies and Italy, stipulates the following reduction on all military activities: "for the purpose of the present Treaty the terms 'demilitarization' and 'demilitarized' shall be deemed to prohibit, in the territory and territorial waters concerned, all naval, military and military air installations, fortifications and air armaments; artificial military, naval and military air units; military training in any form; and the production of war material" [13].

Therefore, the regime concerned operated exclusively during peace time. As M. Chillaud noticed, the non-existence of any kind of fortification or permanent military structure on the delimited territory could be achieved "either retroactively (by the destruction of existing structures) or in a deterrent and preventive mode (by banning future construction)" [2, p. 6].

In contrast to demilitarization, neutralization means that 'no war operations' shall take place within the neutrilized territory, even during an armed conflict. The purpose of the regime concerned is to keep the neutrilized territory completely outside of the theatre of war. However, if an attack is made against the neutralized territory, or if there is a danger of such an attack or invasion, the State exercising sovereignty over this territory is permitted to take military measures to defend it [14, 
p. 616]. For instance, Article 7(2) of the Convention relating to the Non-Fortification and Neutralization of the Aland Islands of October 20, 1921, [15] sets forth the procedure to be followed by the League of Nations and Contracting Parties in case of a situation of aggression against the Åland Islands or against Finland through the Åland Islands. Thus, this provision provided an example of a historical predecessor of the collective self-defence [11, p. 32].

Whereas demilitarization bans setting up all military instalations and military activities provision in a given territory, neutralization excludes this specific territory from being the theatre of war actions. This means, that military installations, especially those, which belong to the domestic authorities, might be deployied on the neutrilized territories. Thus, it could be concluded that "if such military objects remain, a neutralized area may not be demilitarized and a demilitarized area is not ipso facto neutralized either" $[2$, p. 7].

The object of both demilitarization and neutralization could be considered a State's territory, for instance, an island (Korfu) or a group of islands (the Pelagian Islands - Lampedusa, Lampione and Linosa; Aland Islands), its land and water areas, including territorial sea, rivers and straits. Demilitarization could cover all State's territory or a part of it, including reduction of all millitary measures (general demilitarization) or specific military activities, such as, reduction of special types of weapons (partial demilitarization). More specifically, the neutralization of the territory could have different applications in peacetime and during an armed conflict.

Besides, the term 'neutralization' should not be confused with the one of 'neutrality'. The latter means action or declaration made by any State that conveys its neutral status in international relations. Thus, L. Marion asserted that "while neutrality is an institutional norm that is solidly founded in international law, neutralization seems to be a concept that pertains much more to diplomatic strategy, than to a legal approach" [16, p. 227].

In addition, M. Chillaud proposed another distinction to be made between the mentioned terms, having stated that: "while neutrality is a policy practised by one or several states in order above all to avoid certain consequences in time of war, 
neutralization is a quality of limiteted territories that also, or above all, holds good in peacetime" [2, p. 8]. B. Klimenko, having expressed his opinion on this question, said that "neutralization is a legal status of the part of the state's territory, while neutrality is a legal status of the state in general" [4, p. 21].

Legal regimes of both demilitarization and neutralization are provided exclusively by international agreements. Their examples appear to date back to the early Middle Ages, and rules requiring the demolition of fortifications and prohibiting their reconstruction have been found in peace treaties concluded in Europe in the 17th and 18th centuries. Such restrictions were mostly enforced in the form of sanctions : H. Coutau-Bégarie noted that "from antiquity it has been common to impose on the defeated party, aside from the surrender of its fleet, the demolition of its fortifications and the denial of access to certain areas" [17, p. 27].

An early example was the Treaty of Cateau-Cambrésis of April 3, 1559, concluded between France and Spain, which included a prohibition to conduct fortifications in the area of Thérouanne. The Treaty of Peace between the United Provinces of the Netherlands and Spain of January 30,1648, ordered the demolition of fortifications in the border regions of Flanders and along the Scheldt River. The treaty concerned also contained a general prohibition on the establishment of military constructions and strategic canals in the region. In 1768, Denmark ceded several islands in the mouth of the Elbe River to Hamburg, and it was provided that no military installations were to be built on the islands in question $[11$, p. 3-4; 18].

Furthermore, demilitarization as well as neutralization could be resulted from unilateral action of a State (for instance, unilateral decisions of Iceland taken since 1918 that it would be neutral and had no national army) bilateral actions (for instance, the Karlstad Convention signed between Norway and Sweden in 1905 and related to the establishment of a neutralized and demilitarized zone) or multilateral negotiations among States (for instance, the demilitarization and neutralization of the Åland Islands). If such measures are unilateral, they are normally not legally binding but shall be regarded as political commitments. Bilateral and multilateral demilitarization or neutralization are less flexible concepts than the unilateral one because both of the 
former require more specific and binding legal regime which is less easily reversible, if at all [2, p. 9-10].

Practical examples of demilitaritarization and neutralization of territories carried out before the First World War were basically bilateral or multilateral. Commonly, the treaties concluded in that period regulated the terms of peace after the war and imposed obligations regarding demilitarization or neutralization, which States had to undertake (for instance, the Paris Peace Treaty, the Treaty of Peace with Italy signed in 1947 between the Allied nations and Italy regulates demilitarization of certain geographical areas). After the First World War bilateral or multilateral treaties which concerned the terms of demilitaritarization or neutralization were widely concluded. For instance, a bilateral treaty of 1940 between Finland and the Soveit Union on the demilitarization of the Åland Islands and a demilitarized zone declared between North and South Korea/could be mentioned as examples of such international practice. The Korean Armistice Agreement of July 27, 1953, which ended the North/South hostilities established a Military Demarcation Line (MDL) between two States. According to Article 1 (1) of the Agreement concerned demilitarized zone called as buffer zone "shall be established to prevent the occurrence of incidents which might lead to a resumption of hostilities" [19].

Demilitarization and neutralization differ from each other, having individual features. Nevertheless, international practice represents examples of 'nexus of interlocked regimes' of demilitarization and neutralization of certain territory [11, p. 21]. When Finland's sovereignty over the Alland Islands was confirmed by the League of Nations in 1921, the territorial autonomy of the islands and their demilitarization and neutralization have been declared. Both regimes operate simultaneously within certain geographical area.

Another example is the Suez Canal, which was neutrilized under the Constantinople Convention of October 29, 1888. According to Article 4 of the Constantinople Convention: "the Maritime Canal remaining open in time of war as a free passage $<\ldots>$ the High Contracting Parties agree that no right of war, no act of hostility, nor any act having for its object to obstruct the free navigating of the Canal, 
shall be committed in the Canal and its ports". In addition, the Suez Canal was partly demilitarized that is proved in Article 7 of the Convention concerned, according to which: "the Powers shall not keep any vessel of war in the waters of the Canal (including lake Timsah and the Bitter Lakes). Nevertheless, they may station vessel of war in the ports of access of Port Said and Suez, the number of which shall not exceed two for each power" [20]. This example also demonstrates the parallel functioning of demilitarization and neutralization regimes.

Conclusions. Summarizing all of the abovementioned, it is necessary to point out the following conclusions:

1. Demilitarization of territories as well as their neutralization are two different legal regimes to be established for the purposes of peace and security.

2. The analysis of applicable international practice reiterates that legal framework of both regimes could consist of peace agreements with the obligation for a defeated State to demilitarize or neutralize of its territory. After the First World War bilateral or multilateral treaties which concerned the terms of demilitarization or neutralization were widely concluded. Practice demonstrates a significant number of simultaneous functioning of the regimes of demilitarization and neutralization (the Suez Canal, the Åland Islands, neutralized and demilitarized zone between Norway and Sweden, the Svalbard archipelago etc.).

3. Demilitarization and neutralization are not identical phenomena. However, these terms were not considered distinct and separate ones until the conclusion of the Paris Peace Treaty, in which the se concepts concerned were provided with detailed descriptions and interpretations. As a result, contemporary practice provides for different regulation of demilitarization and neutralization regimes.

4. Demilitarized territory is a certain area, which is commonly geographically limited by States, within which no fortifications, permanent military structures and all possible military activities, including instructions and testing of weapons could exist in a peace time.

5. Neutralization means that 'no war operations' shall take place within the neutrilized territory, even during an armed conflict. The purpose of this regime is to 
keep the neutrilized territory completely outside the theatre of war.

6. The common features of these regimes include their functioning within unlimited part of State's territory.

7. Demilitarization bans setting up all military installations and carrying out either military activity in a given territory during peace and war time, whereas neutrilization only excludes certain territory from being a part of the theatre of war. This means, that military installations, especially those, which belongs to the domestic authorities, might be deployed on the neutrilized territories.

8. These regimes could prevent any armed conflict, as such measures will be extremely effective in a post-war relations between States. However, in specific cases it could be complicated to declare such regimes because there are regions of possession of weapons of cultural significance referred to as 'cultural weapons' which are usually not registered or handed back [10, p. 39]. In such geographical areas and within respective countries it is of crucial importance to install the analyzed regimes.

\section{References}

1. Antypenko, V.F., Tymchenko, L.D., Biehlyi, O.V. (2012). Mizhnarodne publichne pravo. (Vol. 1). Kyiv: NAU [in Ukrainian].

2. Chillaud, M. (2006). Territorial Disarmament in Northern Europe. The Epilogue of a Success Story? SIPRI Policy Paper No. 13. URL: https://www.sipri.org/sites/default/files/ files/PP/SIPRIPP13.pdf.

3. Marshall-Cornwall, J.H. (1935). Geografic Disarmament. A Study of Regional Demilitarization. London: Oxford University Press.

4. Klymenko, B.M. (1963). Demylytaryzatsyia y neitralyzatsyia v mezhdunarodnom prave. Moscow: Yzd-vo Ynstytutā mezhdunarodnikh otnoshenyi [in Russian].

5. Protocol Additional to the Geneva Conventions of 12 August 1949, and relating to the Protection of Victims of International Armed Conflicts (Protocol I), 8 June 1977. URL: https://ihldatabases.icrc.org/applic/ihl/ihl.nsf/Article.xsp?action=openDocument\&documentId=1DA6804D31 8A5157C12563CD0051DE08.

6. Commentary of 1987 to Protocol Additional to the Geneva Conventions of 12 August 1949, and relating to the Protection of Victims of International Armed Conflicts (Protocol I), 8 June 1977. Demilitarized zones. URL: https://ihl-databases.icrc.org/applic/ihl/ihl.nsf/ Comment.xsp?action=openDocument\&documentId=6E3CDC1888743A5BC12563CD00435337

7. Ahlström, C. (2004). Demilitarised and Neutralised Territories in Europe. Aland Islands Peace Institute: Mariehamn.

8. Dictionary by Merriam-Webster: America's most-trusted online dictionary URL: https://www.merriam-webster.com/dictionary/demilitarization\#other-words.

9. Salmon, J. (2001). 'Démilitarisation' (Demilitarization), Dictionnaire de droit international public (Dictionary of international law). Brussels: Bruylant.

10. Gleichmann, C. (2004). Disarmament Demobilisation and Reintegration a practical field 
and classroom guide. Stockholm.

11. Åkermark, S., Spiliopoulou, S., Heinikoski, S. (2018). Demilitarization and International Law in Context: The Åland Islands. New York: Routledge.

12. Kingma, K., Schrijver, N. (2013). Demilitarization. Max Planck Encyclopedia of Public International Law.

13. Treaty of Peace with Italy signed at Paris, on 10 February 1947. UNTS, Vol. 49, No.

747 URL: https://treaties.un.org/doc/publication/unts/volume\%2049/v49.pdf.

14. Hannikainen, L. (1994). The Continued Validity of the Dernilitarised and Neutralised

Status of the Aland Islands. Max-Planck-Institut für ausländisches öffentliches Recht und Völkerrecht 54, No. 3.

15. Convention relating to the Non-Fortification and Neutralisation of the Aaland Islands. Geneva, 20 October 1921. Treaty Series, League of Nations. (Vol. 9, p. 211-221). URL: https://treaties.un.org/doc/Publication/UNTS/LON/Volume\%209/v9.pdf.

16. Marion, L. (1992). 'L'introuvable neutralisation du canal de Suez' (The elusive neutralization of the Suez Canal). Stratégique, No. 54.

17. Coutau-Bégarie, H. (1995). Le désarmement naval (Naval disarmament). Paris.

18. Verzijll, J.H.W. (1970). International law in historical perspective. (Vol. III, State territory).

19. The Korean Armistice Agreement signed on July 27, 1953. URL: https://peacemaker.un.org/sites/peacemaker.un.org/files/KP\%2BKR_530727_AgreementConcernin gMilitaryArmistice.pdf.

20. Constantinople Convention signed on October 29, 1888. URL: https://loveman.sdsu.edu/docs/1888ConstantinopleConventionon.pdf.

Роянова I. В., аспірантка кафедри міжнародного права, Національний юридичний університет імені Ярослава Мудрого, Україна, м. Харків.

e-mail: iv.roianova@ gmail.com ; ORCID 0000-0002-0443-1815

\section{Порівняльний аналіз демілітаризованих та нейтралізованих територій у міжнародному праві}

Проаналізовано різні підходи до визначення понять “демілітаризовані” та “нейтралізовані" території, серед яких, зокрема, підхід до терміну “демілітаризації” через визначення сутності “мілітаризачіi”. На підставі проведеного узагальнення міжнародної практики сформульовано наступні висновки: про тотожсність даних феноменів до Першої світової війни $і$ їхню регламентачію угодами про мир; після світових війн переважно укладалися двосторонні та багатосторонні договори, що передбачали демілітаризацію або нейтралізацію територій, або регламентували демілітаризацію та нейтралізачію територій одночасно (Аландські острови, Суецький канал). Зроблено уточнення підходу на демілітаризацію як синонім роззброєння. Робиться висновок, щуо остання є невід'ємною складовою демілітаризачії поряд із демобілізаџією. Костатовано, щуо недоцільним $\epsilon$ ототожнення понять “нейтралізації" та “нейтралітету”, адже останні визначають правовий статус держави, тоді як нейтралізація - правовий статус частини території держави. На підставі порівняльної характеристики режимів демілітаризованих та нейтралізованих територій за такими критеріями, як об'єкт, юридичні підстави, часові межі дії, визначено їх як спільні, так і відмінні риси. Серед відмінних рис звертається увага на наступне: режим демілітаризованої території діє в мирний $і$ воєнний час та забороняє військову діяльність в будь-яких формах в межах иієї території; режим нейтралізованих територій передбачає заборону використовувати частину територї держави як театр для воєнних дій. Робиться висновок, щзо демілітаризація та нейтралізація територій забезпечує мир та безпеку, $і$ виконує функиію попередження збройних конфліктів та позитивно впливає на врегулювання післявоєнних відносин між державами.

Ключові слова: демілітаризація; нейтралізація; демілітаризовані території; 
роззброєння; нейтралітет; Аландські острови.

Роянова И. В., аспирантка кафедры международного права, Национальный юридический университет имени Ярослава Мудрого, Украина, Харьков.

e-mail: iv.roianova@gmail.com ; ORCID 0000-0002-0443-1815

\section{Сравнительный анализ демилитаризованных и нейтрализованых территорий в} международном праве

Проанализированы различные подходы к определению понятий “демилитаризованые”" u “нейтрализованые” территории. На основании обобщения международной практики сформулированы следуюшие выводы: о тождественности данных феноменов до Первой мировой войнь и их регламентачии соглашениями о мире; после мировых войн преимущественно заключали двусторонние $u$ многосторонние соглашения, предусматривающие или демилитаризаџию, или нейтрализациюю территорий, либо оба режима одновременно. Сделано уточнение относительно подхода на демилитаризацию как синоним разоружения. Предлагается рассматривать последнее в качестве неотъемлемой составляющей демилитаризации вместе с демобилизацией. Констатировано, что является нецелесообразным отождествление понятий “нейтрализачия" и “нейтралитет”, поскольку последнее определяет правовой статус государства, тогда как нейтрализация правовой статус части территории государства. На основании сравнительной характеристики режимов демилитаризованных и нейтрализованных территорий по таким критериям, как объект, юридические основания, временные предель действия, определень их как общие, так и отличительные черты. Формулируется вывод о том, что демилитаризачия и нейтрализация территорий обеспечивает мир и безопасность, а также выполняет функцию предупреждения вооруженньх конфликтов и положительно влияет на урегулирование послевоенных отношений между государствами.

Ключевые слова: демилитаризация; нейтрализация; демилитаризованные территории; разоружения; нейтралитет; Аландские острова

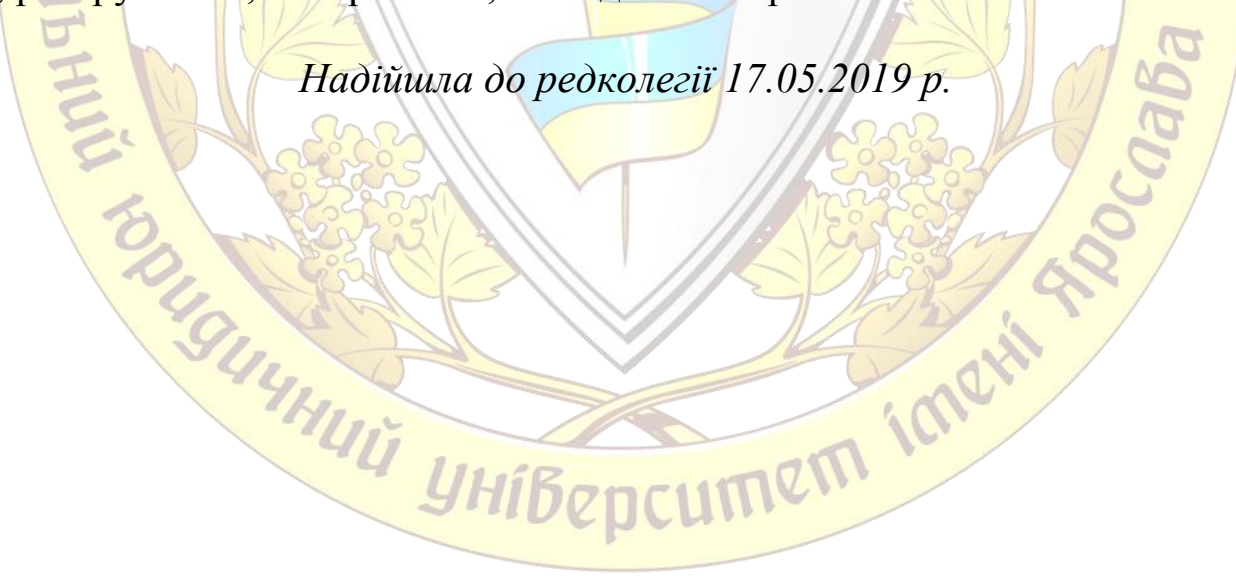

